\title{
Trade And Industrial Policy Analysis With Specific Reference To Automotive Industry Programmes: Lessons For Developing Countries
}

\author{
Maylene Y. Damoense, (Email: maylene.damoense@buseco.monash.edu), Monash University, South Africa
}

\begin{abstract}
Over the last two decades the global auto industry has undergone important structural transformations and policy reforms posing complex challenges for low-volume automobile producing countries. More specifically, during the 1990s, rapid growth in sales and production were experienced in the global auto market, which has interestingly, been largely attributable to strong growth registered in emerging markets instead of the Triad regions. This paper provides a sectoral perspective analysing trade and industrial policies of selected emerging auto countries and concludes with recommendations for future automotive policy particularly for South Africa and other developing countries that are important to developing internationally competitive and sustainable automotive sectors.
\end{abstract}

\section{INTRODUCTION}

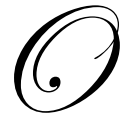

ver recent years the global automotive industry has undergone important structural transformation and policy reforms, particularly posing complex challenges for low-volume automobile producing countries, including South Africa, Australia and others. For many economies, their automotive industries represent economically strategic sectors, contributing significantly to manufacturing value-added, employment and national income. The automotive industry, for the most part of this paper, includes the manufacture of auto components and assembly of vehicles.

Globalization of the world auto market commenced from the late 1980s. Several countries auto industries experienced dramatic restructuring since the mid-1980s, influenced by government strategy to develop them into more efficient industries. Since the mid 1990s, the strong growth in global sales and production in the world auto industry were largely attributable to growth in emerging markets rather than the Triad regions (North America, Europe and Japan). Furthermore, growth in emerging auto markets, especially India and China, are expected to reach record levels in 2004 (EIU, 2004). Auto firms in the Triad regions are increasingly looking for opportunities to enter emerging markets where market penetration is relatively low and populations are sizeable, among others. Global Original Equipment Manufacturers (OEMs) and auto suppliers are increasingly seeking to outsource their operations to low cost countries, such as India, Brazil, China and Malaysia. There is ongoing migration from high cost countries to lower cost countries. Research findings suggest that OEMs tend to invest in production facilities outside their home countries for a variety of reasons, which include low-cost locations, potential for growth, government incentives and global strategies of transnational corporations (TNCs), etc. (ACMA, 2004; Humphrey, 2003; Cavalcante \& Underman, 2004).

During the 1960s and 1970s, automotive sectors of developing countries have traditionally been heavily protected by a series of protective instruments such as quantitative restrictions (QRs), mandatory domestic content requirements, high import tariffs, and quotas. Since the 1980s, there has been a transfer from import substitution to export orientation policies for most developing markets. As trade liberalization and globalization accelerated in the 
1990s, especially following the outcome of the General Agreement of Tariffs and Trade (GATT) and Trade Related Investment Measures (TRIMS) under the World Trade Organisation's (WTO's) Uruguay Round of 1994-1995, tariffs have been lowered and a number of protective measures in many developing countries discontinued (QRs, local content regulations, etc.). Further, under the auspices of the Uruguay Round accord, Trade Related Investment Measures (TRIMS) were to be phased-out spanning over five years for developing countries. However, many emerging and developing countries combined trade and investment liberalization in conjunction with measures that continually protected their auto domestic industries. In particular, countries like India and Brazil have violated TRIMS by maintaining local content provisions and foreign exchange balancing requirements.

The success of the Indian, Australian and Chinese auto industries, as pointed out in this paper will provide important lessons for South Africa and other developing countries. Thus the paper looks at trade and industrial polices, with reference to auto policies of these countries and considers the impact of recent policy reforms on the development and performance of their respective automotive industries. An account of the role of government policy in shaping the industries over the past decade is reviewed. The paper will also examine the impact of recent automotive policy reforms on the performance of automotive industries with respect to domestic production, employment, automotive exports and imports, and the automotive trade balance. The paper focuses primarily on auto programmes relating to light vehicles, which include both light passenger vehicles (LPVs) and light commercial vehicles (LCVs), and auto components. Overall the purpose of the paper is to draw lessons from the experiences of China, India and Australia with a view to make recommendations for future automotive policy in South Africa and other developing countries within the framework of an ever-changing competitive global automotive environment.

More specifically, in South Africa, over the last two decades, the local automotive industry has undergone a chain of important structural policy reforms to develop it into a self-sufficient and competitive manufacturing subsector. During the 1960s and 1970s the government played a key role in trade and industrial policy by protecting the local industry through import restrictions. During the late 1980s, export promotion strategies were implemented, to enhance the automotive export performance of the industry and promote global integration of local firms with parent firms, which was crucial for the survival of the automotive industry. However, the economic costs associated with government export support schemes have noted to be quite high, increasing the effective protection rate of the industry (Tacaks, 1992; Pursell, 2001; Flatters, 2002; Damoense \& Simon, 2004).

Besides this introduction, the paper is arranged in four further sections. Section 2 briefly outlines main trends in the global auto industry, including trade policy aspects influencing auto activities in emerging and developing nations. The next section looks at country-specific auto policy reforms in a few emerging markets, including South Africa and considers the similarities and differences in policy strategies and the role of governments. Section 4 discusses some key features of the performance of the auto industry in respect of domestic production, the auto trade balance, automotive employment and technology issues. Section 5 provides some lessons for South Africa and other developing countries from the Chinese, Indian and Australian experiences. Finally, section 6 closes with the main conclusions of this paper.

\section{RECENT MAJOR DEVELOPMENTS IN THE GLOBAL AUTO INDUSTRY}

World vehicle production has been rising steadily during the 1990s. Figure 1 show trends in world vehicle production by region for the period 1995 to 2003 . Between 1995 and 2000 vehicle production in the world auto market increased by 18 per cent from about 49 million units to just over 58 million units of vehicles. Most of the increase can be explained by the spurt of growth concentrated in a few emerging markets, mainly China and India, which form part of the Asia Pacific region, each contributing 6 per cent and almost 2 per cent respectively in 2002 to world vehicle production.

By 2015, eighty per cent of the increase in the world's consumption for automobiles is likely to transpire in developing nations (Audet, 1998). This anticipated development is likely to pose important implications for world automotive industry location patterns in the future. 
Figure 1. World Vehicle Production By Region (In ‘000 Units), 1995-2003

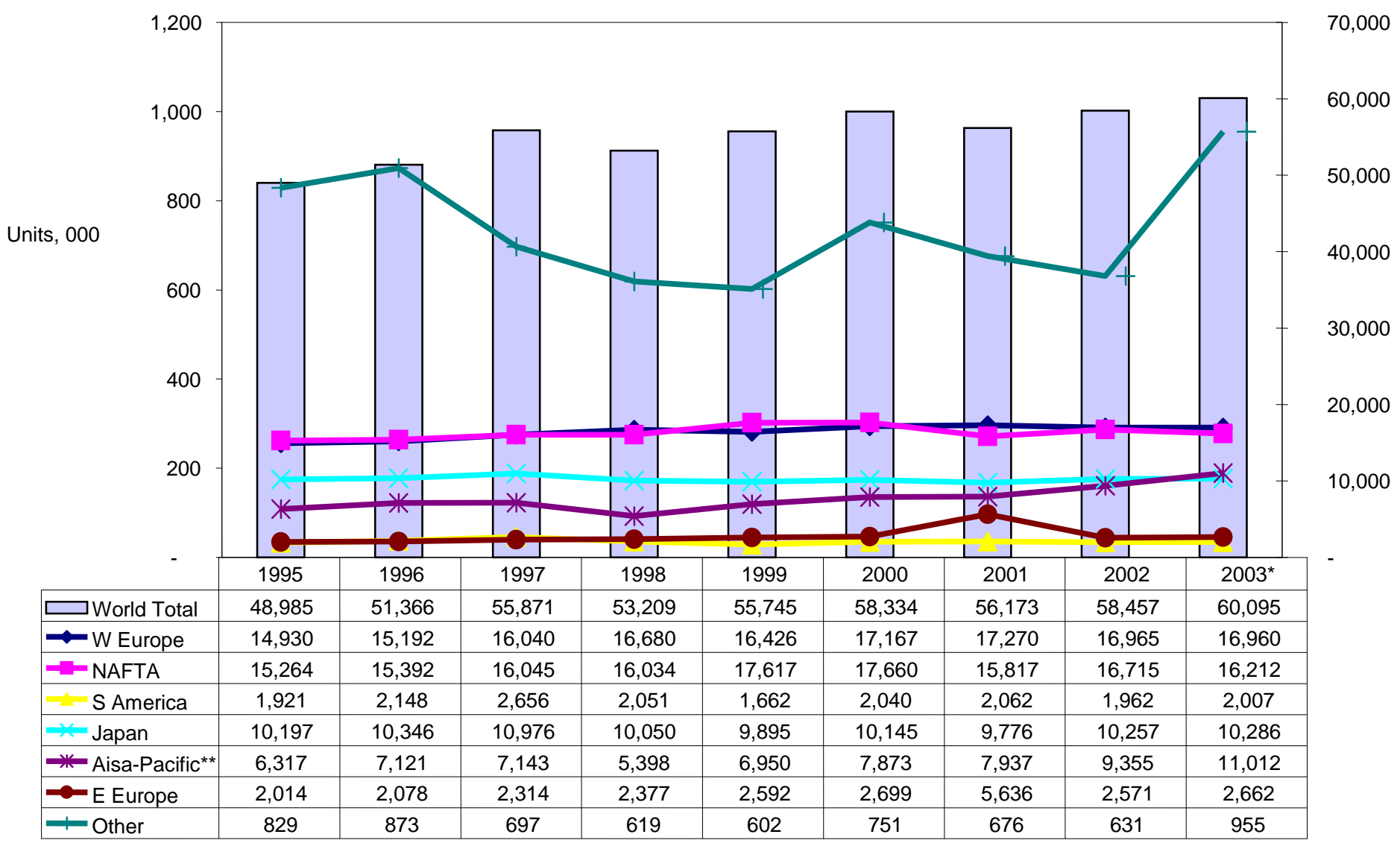

Sources: IMF Auto Report (2000), IMF Auto Report (2004). *Forecast. **excludes Japan, includes Australia and New Zealand. Notes: Vehicle production figures denote the sum of car and commercial vehicle figures. 
Expansions of the Chinese and Indian auto markets are expected to accelerate in the near future. Already, the Economics Intelligent Unit (EIU) project that China and India's economies will grow vigorously by 6.7 per cent and 6.5 per cent respectively (Economist, 1999), hence we can expect stronger trends in private auto sales. In contrast, vehicle demand in the Triad regions has reached maturity and remains stagnant. The demand growth for new cars in the Triad regions has been growing at an average rate of less than 1 per cent per annum for the past decade and this trend will possibly continue (Veloso \& Kumar, 2002), making these emerging markets more desirable destinations for TNC investments.

Globally, free-trade (FT) agreements are becoming increasingly important for conducting trade and business. The emergence of the new trade geography, in particular regional-scale trade cooperation involving greater trade and investment flows among developing nations located in different regions are befitting. The increasing number of regional trade agreements (RTAs) amongst developing nations (South-South cooperation) has important implications for the automotive industry. For instance, MERCOSUR (Common market of the Southern Cone, which includes Brazil, Argentina, Paraguay, and Uruguay) is the third largest trading block after the European Union (EU) and NAFTA (North American Free Trade Agreement) Canada, Mexico and the United States); all have specific automotive provisions. Others are: Asia-Pacific Economic Cooperation (APEC) that includes countries like Australia, New Zealand, Malaysia, Japan, etc.; ASEAN (Association of South-East Asian Nations) region, include countries such as Thailand, Malaysia, Philippines, Indonesia, among others. In Developing Africa, SACU (Southern African Customs Union) has been established to include South Africa, Botswana, Namibia, Lesotho and Swaziland) and there are talks of forming regional trade agreements (RTAs) with India and MERCOSUR States, among others. For developing countries these (RTAs) has to a large degree resulted in greater market access arrangements to larger markets, flows of foreign direct investments (FDI), transfer of technologies, knowledge-sharing, participation in global industry production chains, etc. (Bardouille, 2001; UNCTAD, 2004; Cavalcante \& Underman, 2004).

The conduct of major vehicle manufacturers and vehicle component firms has been dramatically revolutionized. In recent times, responses and strategies of major auto makers include greater technological innovation. Increased consolidation amongst OEMs are occurring in the form of mergers and acquisitions (M\&As) and joint ventures (JVs). It is projected that there will be a substantial upsurge in M\&As over the next few years. This development is likely to lead to fewer TNCs in the future - it is predicted that by 2015, fewer than five TNCs will remain and dominate the world auto industry. Further, TNC auto makers are following standardization strategies common platforms and interchangeable modules with a view to cope with proliferation and to achieve scale efficiency. For instance, consider 'Fiat's world car strategy' also known as 'Project 178'. The project includes building related vehicles on the same platform, and permits a variety of body profiles acceptable across geographical boundaries of the world to cater for international market needs. There are five body designs that include the Fiat Palio (three and five-door hatchback), Palio Weekend (station wagon), Fiat Sienna (three-box saloon), a van and a pick-up (Iniamart.com, 2004).

New technologies and the knowledge-based economy is driving the global auto industry and influencing global strategies of TNC auto firms. Global strategies of TNCs include being less engaged in production and assemblage transferring greater accountability toward auto component supplier firms. This approach has led to the restructuring of the component auto market. The component industry supply chain has been configured into the following roles; (i) systems integrator, (ii) global standardizer-systems manufacturer, (iii) component specialist and (iv) raw material supplier. In addition, component specialists comprise of further three levels, namely, component manufacturer and subassembly manufacturer (Veloso \& Kumar, 2002) ${ }^{1}$.

Auto manufacturers are increasingly responding to the diverse needs of vehicle consumers, and to meet higher environmental (emission filters, engine systems - hybrids, fuel cells) and safety (airbags, ABS, etc) standards enforced by government policy. For instance, since April 1995, all passenger cars must have built-in catalytic converters. This trend has contributed to recent automotive technology advances and innovations experienced in the global industry. The emergence of new technologies is influencing the evolution of the car. Modern cars are increasingly incorporating greater levels of technology. For instance, there are rising proportions of electronics and

\footnotetext{
${ }^{1}$ See Veloso \& Kumar (2002) for further discussions.
} 
semi-conductor content in an average passenger vehicle. In 1995, electronics intensity in an average motor car have increased from 2.5 pent in 1985 to 17 per cent in 2000, to a further estimated 22 per cent by 2005 (FCAI, 2002).

Vehicle buyers have become more urbane, and are more becoming demanding and are increasingly interested in service strategies of auto firms. Thus, reliability, greater assortment of vehicle models, quality and enhanced vehicle functioning are key aspects for the current sophisticated vehicle buyer. The diverse needs of vehicle consumers are determined by income levels, government policy, societal ethos and vehicle features, which also contributes to the augmented proliferation of vehicle models in the global auto market and imply greater challenges for by vehicle manufacturers.

\section{WTO RULES AND ITS INFLUENCE ON AUTO POLICY}

Prior to international trends towards free trade, many low-volume auto producing countries were heavily protected by high levels of tariffs and an array of protective instruments (local content regulations, quantitative restrictions, foreign investment limits, and export incentives). This type of strategy by governments was to insulate domestic assemblers and component producers from competition by imports and shelter the industry's trade balance. During the 1980s, governments of developing countries reoriented industrial policy away from import substitution towards encouraging exports following more liberalized trade regimes with respect to autos. From that time automotive exports have become increasingly important for the development and expansion of most developing economies. By the late 1990s, auto industries in developing markets were being transformed by accelerated trade liberalization efforts, including the inflows of new investments by major TNC auto firms.

In compliance with the WTO's Uruguay Round Agreement of GATT to reduce tariff barriers in 1994, tariffs have been falling for most auto producing countries ranging from high levels of 57.5 per cent and 50 per cent in South Africa and India respectively to lower levels of 22.5 per cent for Australia in 1997 (Damoense, 2001). Further tariff reforms in South Africa and India has since occurred and is presently at the 30-40 per cent level. Australia's tariff levels are much lower at 15 per cent. In addition, the Uruguay Round Agreement on Trade Related Investment Measures (TRIMS) required that developing countries phase out such measures over a five year period starting 2000. TRIMS instruments include local content regulations, import-export complementation (IEC) requirements or export facilitation (EF) schemes, etc. Notwithstanding, the TRIMS agreement, many developing countries continued on this path by re-instituting local content policy - renamed indigenization (eg. India). Other measures such as export facilitation arrangements, also known as import-export complementation (IEC) are inconsistent with TRIMS regulation but are still widely applied to a number of developing countries domestic auto industries, such as South Africa, albeit it is presently being phased down. Australia's EF scheme no longer exists and has been replaced by the Automotive Competitiveness Investment Scheme (ACIS) in January 2001. More on Australia's ACIS is discussed in the next section.

Table 1 below provides a summary of automotive policy developments in China, India, Australia and South Africa during the late 1980s-early 1990s to present times. It is noteworthy that at some point or the other during the evolution of their auto policies similar protective instruments have been employed by all countries, albeit differences in, for instance, actual levels of local content, tariffs, export credits, etc. These protective measures will continue to add high economic costs to these auto industries even though most of them are successful exporters of auto vehicles and auto components, and are experiencing massive inflows of FDI from TNCs. These auto countries will persist with problems that include small domestic markets that are fragmented, overcapacity, and no benefits of reaping scale economies, high-priced domestic vehicles, export-dependency, among others. Further, it should also be pointed out that the structures of their macro-economies and auto industries are not the same.

Table 2 below provides key indicators of the countries concerned and will be referred to later in the paper. As government assistance prevails, tariff reform and investment inflows continue, the auto industries of developing countries remain semi-protected. Empirical evidence supports the hypothesis that protective measures as discussed here contribute to increasing the effective protection of the domestic industries of developing nations by imposing high economic costs on them and vehicle consumers resulting in economically inefficient local auto industries. 
Table 1. Synopsis Of Recent Auto Policies For Selected Countries: China, India Australia \& South Africa

\begin{tabular}{|c|c|c|c|}
\hline Country & Period & Policy Developments & Key Policy Instruments \\
\hline \multirow[t]{2}{*}{ China } & $1994-2000$ & $\begin{array}{l}\text { Implementation Policy of the Motor Industry } \\
\text { (IPMI) }\end{array}$ & $\begin{array}{l}\text { Local content regulations, tariffs \& } \\
\text { quota's, limit foreign investment. }\end{array}$ \\
\hline & 2001-2005 & New Auto Policy - Tenth Five-Year Plan & $\begin{array}{l}\text { Tariff reform, import restrictions, restrict } \\
\text { foreign investment, encourage local } \\
\text { investment. }\end{array}$ \\
\hline \multirow[t]{3}{*}{ India } & 1992 & Phased Manufacturing Programs (PMP) & $\begin{array}{l}\text { Local content rules, import licensing, } \\
\text { tariffs. }\end{array}$ \\
\hline & 1997 & Memorandum of Understanding (MoU) & $\begin{array}{l}\text { Tariffs, “indigenization”, "discretionary } \\
\text { import licensing”, limit foreign equity, } \\
\text { import-export (IE) requirements. }\end{array}$ \\
\hline & 2001-2010 & New Auto Policy & $\begin{array}{l}\text { Discontinued import licensing, tariff } \\
\text { reform, excise duties, infrastructural road } \\
\text { development, tax breaks, etc. }\end{array}$ \\
\hline \multirow[t]{3}{*}{ Australia } & 1982 & Export facilitation scheme & $\begin{array}{l}\text { QRs, export credits, local content, and } \\
\text { tariffs. }\end{array}$ \\
\hline & $1985-2000$ & Button Car Plan & $\begin{array}{l}\text { EFS, tariff reform for both CBUs and } \\
\text { CKD. }\end{array}$ \\
\hline & 2001-2005 & $\begin{array}{l}\text { Automotive Competitiveness Investment Scheme } \\
\text { (ACIS) }\end{array}$ & $\begin{array}{l}\text { ACIS to replace EFS. Tariff reform } \\
\text { continued. }\end{array}$ \\
\hline \multirow{3}{*}{$\begin{array}{l}\text { South } \\
\text { Africa }\end{array}$} & 1989-1995 & Phase VI: Structural adjustment program & Local content regulations \& IEC \\
\hline & $1995-2000$ & $\begin{array}{l}\text { Motor Industry Development Program (MIDP): } \\
\text { First phase }\end{array}$ & $\begin{array}{l}\text { Local content rules terminated. Tariff } \\
\text { phase-down for both CBUs and CKDs, } \\
\text { IEC scheme continued, DFA \& SVI }\end{array}$ \\
\hline & $2000-2012$ & MIDP: Second phase & $\begin{array}{l}\text { Tariff phase-down continue, IEC phase } \\
\text { down, new DFA \& PPA introduced, SVI } \\
\text { to terminate }\end{array}$ \\
\hline
\end{tabular}

Sources: Runckel \& Associates (2004), Damoense \& Simon (2004), Pursell (2001); Veloso \& Kumar (2002), IMF Auto Report (2000), IMF Auto Report (2004), SAIM (2004).

Table 2. Key Indicators For Selected Countries, 2002

\begin{tabular}{|l|c|c|c|c|}
\hline Indicator & South Africa & Australia & India & China \\
\hline Population, (millions) & 45.3 & 19.7 & $1,064.4$ & $1,288.4$ \\
\hline GDP (billions of dollars) & 106.4 & 409.0 & 510.2 & 1,266 \\
\hline Real GDP growth, 2003 (\%) & 1.9 & 3.0 & 7.4 & 9.1 \\
\hline GDP per capita (constant 1995 US\$) & 4,201 & 24,455 & 493 & 825 \\
\hline No. of assemblers & 8 & 4 & 24 & 120 \\
\hline $\begin{array}{l}\text { Size of the total passenger vehicle } \\
\text { market (000 units) }\end{array}$ & 232 & 540 & 31 & \multirow{2}{*}{126} \\
\hline Trade (\% of GDP) & 63 & 42 & 1 & 55 \\
\hline Current account balance (\% of GDP) & 1 & -4 & 3.4 & 3 \\
\hline $\begin{array}{l}\text { FDI inflows, 2002 (billions of dollars) } \\
\text { FDI net inflows (\% of GDP) }\end{array}$ & 0.8 & 14.0 & 4 & 52.7 \\
\hline
\end{tabular}

Sources: Veloso \& Kumar (2002), NAAMSA (2003), EIU (2004), World Bank (2004), IMF Auto Report (2004). 


\section{The Auto Industry In China}

The automotive industry in China has undergone dramatic restructuring and consolidation in recent times. China's auto industry is regarded "as one of the most overheated industrial sectors in China" (China Embassy, 2004). A novel auto policy for China has recently been launched by the National Development and Reform Commission (NDRC), effective 2 June 2004. This new policy will replace the Chinese government's Implementation Policy of the Motor Industry (IPMI) that was pioneered in February 1994. The main theme of the new policy is to slow down investment that has reached exceptional levels and to promote domestic private vehicle consumption (Runckel \& Associates, 2004). Other features of the new auto policy include tariff reforms and the discontinuation of import permits and quota's. In 2002, China cut tariffs on CBU imports from a high 70-80 per cent to 43.8-50.7 per cent, which is still high according international standards. Tariffs are to be reduced further in 2003 to 38.2-40.0 per cent (GI, 2004).

China has the largest population in the world exceeding 1.0 billion persons. The country's GDP per capita stands at US\$ 825 and the average unemployment rate is almost 10 per cent (EIU, 2004). China employs in its auto sector about 1.85 million workers (Veloso, 2002). The Chinese market is expected to continue growing - 150 million cars are set to occupy the streets by 2015. In 2003, around 11,000 more cars merged onto Chinese roads - 4 million new private cars during the year. Auto sales increased by 60 per cent in 2002 and exceeded 80 per cent by the first half of 2003. Chinese domestic output is expected to reach 4.2 million in 2003 compared with 3.2 million cars in 2002 (Ministry of Commerce, China, 2003).

China's three major state-owned auto firms (First Automotive Work Corp, Shanghai Automotive Industry Corp and Dongfeng Motor Corp) dominate vehicle production, accounting for 95.9 per cent of the 15 state-owned enterprise auto firms' profits (GI, 2004). Each of the three has yearly capacity of at least 500,000 units, operated mainly through JV with foreign TNCs. Challenges in the Chinese market include insufficient scale of production, only a few Chinese auto makers have capacities exceeding 100,000 units of vehicles (Ministry of Commerce, China, 2003). Capital investments in China's auto industry amounted to US\$ 12 billion for the period 1996 until mid-2003 (IMF, 2004). The Chinese auto industry is positioned to become a global supplier of auto components and vehicles. Accordingly, Ford erected an exporting sourcing centre in Shanghai and expect to source US\$ 1 million worth of materials from China in 2003 (Thursfield, 2003). DaimlerChryler and General Motors also plan to increase export vehicles and import kits to China following the announcement of China's new auto policy by the National Development and Reform Commission.

\section{The Auto Industry In Australia}

The Australian automotive industry comprise of four OEMs (Toyota, Ford, Holden and Mitsubishi) producing over 400,000 units of motor vehicles annually. Australian OEMs tend to be more competitive in producing the upper medium size category of passenger cars (such as the Ford Falcon and Holden Commodore, which are locally produced models). Although, the industry is regarded as being mature according to international standards, domestic production have increased over the last five years, primarily driven by exports. Reasons for growth include a range of industry specific measures that complement government policy, well-developed infrastructure, skilled workforce, availability of raw materials, among others. Model rationalization has been successful in that 13 vehicle models have been reduced to 6. Productivity levels have improved dramatically. Strong growth in Australia's automotive exports has been experienced in recent years. The value of total automotive exports amounted to about US\$ 2.7 billion for the 2002 financial year - US \$ 1.6 billion for automotive vehicles and almost US\$ 1.1 billion for automotive components (DFA, 2003). Australia exported over 111,000 vehicles in 2002. Australia's chief export destinations include New Zealand, the Middle East and the USA.

Australia's GDP per capita is US\$24, 455 the highest compared to the rest of the countries under study in this paper with an average unemployment rate of 6.4 per cent in 2002. In 2001-2002 the industry contributed about 1 per cent to the national economy's gross domestic product (GDP) and employment in the industry, including components and vehicles, was in the region of 63,000 workers. 
As indicated in table 1, Australia's Button Car Plan was introduced in the mid-1980s and expired on 31 December 2000. The main features include an export facilitation scheme (EFS) and the gradual reform of tariffs, which are features shared with many low-volume auto producing countries, such as South Africa. In terms of the export facilitation scheme (EFS), OEMs and component manufacturers may earn compensatory import tariff rates as a result of their export efforts. In addition, OEMs are able to import a certain value worth of motor parts duty-free depending on their export values (Mascitelli, 1999). EFSs, which in effect operate as export subsidies, are not consistent with WTO regulations. Under the Button Car Plan, tariffs were reduced from 57.5 per cent in 1987 to 17.5 on 1 January 1999. In January 2001, Australia introduced the new ACIS. Initially, it was suppose to run for five years until 31 December 2005. From January 2001 the tariff rate on both passenger vehicles and components will be set at 15 per cent. Thereafter, a further 5 per cent reduction until 10 per cent is to be reached in 2005 . Tariffs will remain at 10 per cent until the end of December 2009. From 1 January 2010, tariffs will again be reduced to 5 per cent until 2015. The ACIS was subsequently extended until 2015 to provide transitional assistance to the automotive industry to encourage competitive long-term investments by local firms and hence stimulate job creation and in sequence sustainable growth.

Effectively the ACIS replaced the EFS. The ACIS offers import duty credits, which can be rebated against import duties on eligible automotive imports. The ACIS authority expects forgone revenue to the Australian economy will be equivalent to US\$ 1.1 billion due to the proposed allowances offered to the industry under the ACIS over the five years. The value of assistance offered to individual firms under the ACIS will be restricted to 5 per cent (in any given year) of its domestic automotive sales based on the previous year. New investments under the scheme are forecast to be in the region of US\$ 2.2 billion by 2005. In addition 5,000 jobs are expected to be generated, as well as US\$ 3.3 billion worth of automotive exports by 2005. A study conducted by Deloitte Touche Tohmatsu in 2002 considered the impact of Australia's ACIS on domestic vehicle producers. The study revealed that ACIS benefits are crucial to attract and maintain investments from parent companies and international partners. In particular, total projected R\&D expenditure would increase substantially 'with ACIS' over the period 2001 to 2005 . The study further suggests that in the absence of ACIS assistance the industry could expect vehicle output to fall by about 170,000 units of vehicles per annum over the five-year period up until 2005, and dramatically reduce R\&D expenditures for the same period. Australia spends a little over US\$ 200 million per annum on R\&D (FCAI, 2002).

Since the opening up to international competition, there has also been intense competition from importing completely built-up units (CBUs). Almost 70 percent of vehicles sold in Australia are imported. Total automotive imports totaled about US\$ 9.8 billion 2002; US\$ 6.6 billion and US\$ 3.2 billion for vehicles and components respectively (DFA, 2003). With respect to employment in the industry, planned closures by the Japanese car maker, Mitsubishi, of its engine plant and foundry at Lonsdale and Tonsley Park in South Australia is expected to cost the industry 670 and 350 jobs respectively. The cutting back of firm's operations will have a significant adverse impact on automotive manufacturing and employment in the Australian state (EIU, 2004). The decline in employment levels in auto industries due to plant closures is a major concern for many developing countries. The challenge for the Australian automotive industry is to maintain feasible levels of domestic auto sales and sustain employment levels, and also become increasingly internationally competitive and attract new investments.

\section{The Auto Industry In India}

By tradition, India has been one of the most protected economies in the world. More specifically, India's automotive industry has been subjected to a range of protective instruments, including local content rules, strict licensing accord on investments and imports. In December of 1983, India's Maruti Udyog Ltd., a joint venture was formed between the Indian government and Japan's Suzuki, to produce the first affordable passenger vehicle that catered for the needs of the average consumer. The Indian car market was dominated by three large firms - (1) Maruti Udyog Ltd., (1) Premier Automobiles Ltd. and (3) Hindustan Motors. By 1993 the Indian auto industry became delicensed and foreign equity participation increased to 51 per cent automatically however permission for up to 100 per cent may be granted by permission from the Foreign Investment Promotion Board (FIPB) of India. This policy development engendered the entering of the major automakers into the Indian market, mainly through joint venture (JV) arrangements instead of wholly-owned subsidiaries. FDI for passenger vehicles amounted to $\$ 0.51$ billion for the period August 1991 and December 1996. Import restrictions still remain high in automobile production. Vehicle 
importers, wishing to undertake production in India are required to sign a Memorandum of Understanding (MoU) requiring signatories to abide by a number of rules, among them local content rules. Presently, India has MoU's with associations in 17 countries.

India has a huge population and is the second most populated country in the world with an estimated population in excess of 1.0 billion people. They have very low income levels and the country's GDP per capita is US\$ 493 with an unemployment rate of 9.5 per cent (EIU, 2004). As mentioned earlier, Indian auto policy has protected the industry over many years. Table 1 provides a brief account of key policy instruments under India's current auto policy. Excise duties on passenger vehicles will fall from 32 per cent to 24 per cent and is likely to translate into lower vehicle prices. The National Calamity Contingent Duty (NCCD) of 1 per cent enforced on passenger and multi-utility vehicles, and two-wheelers is expected to increase input costs of producers that may adversely affect sales. Domestic and export sales of passenger vehicles exceeded $1 \mathrm{~m}$ in 2003-04, while that of two-wheelers reached $5 \mathrm{~m}$. Sales of cars and utility vehicles increased by 32 per cent and that of motorcycles and scooters rose by 13 per cent. Sales of luxury vehicles grew faster than those of cheaper models, by contrast, truck and bus sales were sluggish (EIU, 2004).

India's component industry's output totaled US\$ 4,470 million in 2001-2002 (ACMA, 2004). Similar to South Africa, India's auto component industry is highly export oriented. In 1997-1998, component exports totaled US\$ 330 million and increased more than two-fold to US\$ 760 million by 200-2003 (ACAM, 2004). Auto component investment expenditure in India reached US\$ 2,645 million in 2002-2003 and is expected to rise to over US\$ 3,100 million by 2003-2004. India's main export destinations for auto parts include the United States of America (28 per cent), Europe (28 per cent), Asia (27 per cent) and Africa (11 per cent). Main exporting component parts are engine parts, drive transmission and steering parts, suspension \& breaking parts, electrical parts, radiators, gears, fuel injection parts, among others. Indian auto components are cost competitive due to the availability of appropriate levels of automation and the low cost nature of automation in the industry, and has competencies in information technology (IT) based engineering solutions for product and process assimilation (ACMA, 2004). Large firms like Electrolux, Caterpillar, Kautex Textron and Eaton plan to outsource auto components worth more than US\$ 1.3 billion by 2005 from Indian component suppliers.

Two main concerns regarding India's auto sector are poor roads and infrastructure and environmental pollution. But since 2000 with the implementation of India's Golden Quadrilateral of National Highways development project that is estimated to cost just over US\$ 5 billion, the picture is about to change and is likely to have huge impacts on the auto industry and economic growth as a whole. In addition, infrastructural development of 48 new road projects will be carried out at a cost of about US\$ 8.2 billion (ICRA, 2003-04). This will stimulate local demand for passenger cars. The auto industry anticipates producing 1 million units of vehicles per annum by 2005-2006. Thus, India represents one of the most desirable markets for the automotive industry in the future.

\section{The Auto Industry In South Africa}

As with most developing countries, over the last few decades the South African automotive industry has undergone significant structural change and policy reforms. In the midst of transformation, the local industry is experiencing robust growth and has magnetized substantial foreign investments by major TNCs. The motor sector in South Africa contributes about 6.3 per cent to the national economies GDP and employs in the region of 279,700 workers (NAAMSA, 2002). It is the third largest exporting sector in the country (DTI, 2003). The local automotive industry is a large net user of foreign exchange; the sum of automotive exports was US $\$ 3.8$ billion and that of imports almost US $\$ 4.8$ billion in 2002 (DTI, 2003).

South Africa's automotive industry has been experiencing important automotive policy reforms, especially since the late-to-mid 1990s. Following the progress toward greater trade liberalization, a structural adjustment programme for the motor industry was instituted on 1 March 1989. The primary objective of this programme was to save foreign exchange and to encourage export growth of automotive products. By the mid-1990s, the local industry came under scrutiny because of its languorous performance during the 1980s and early 1990s. This led to the implementation of the Motor Industry Development Programme (MIDP) which became effective 1 September 1995. The impact of the MIDP was revisited in 2000, and recommendations were made. The main positive outcome of the 
MIDP includes the strong performance of automotive exports, both in terms of CBUs and CKDs. This has been facilitated by local OEMS increasingly becoming part of global networks of parent firms providing them access to export markets and injecting foreign direct investment (FDI) inflows. In addition, the instruments of the MIDP, which include lowering of tariffs, import-export complementation (IEC), and the productive asset allowance (PAA) schemes, have provided important incentives for increasing capital investments and R\&D efforts in the industry. Capital investment outlays by local auto firms increased by 73 per cent from about US\$ 0.15 billion in 2000 to US\$ 0.26 billion in 2002 (DTI, 2003).

We expect that as globalization progresses, in particular the spate of mergers and acquisitions (M\&A), motor vehicle prices will drop (Tcha \& Kuriyama, 2003). This has certainly not been experienced in South Africa; car prices remain too high to afford for many South Africans. According to Brand Pretorius of McCarthy, it takes a US worker an estimated 17 days of work to pay for the cost of a new vehicle compared to about 2 years of work for a South African worker. Vehicle pricing in South Africa remains a concern for vehicle buyers. Setting car prices is a complex exercise that involves many variables, including inflation, level of local content, import content, exchange rate trends, duties and taxes, export volumes, productivity trends, economies of scale, market forces and return on investments (Vermeulen, 2004).

The MIDP will be extended to the year 2012 with continued government support and complex mechanisms that continue to protect the local industry. A preliminary study done by Damoense \& Agbola (2004) indicate that together, current levels of local content, import-export requirements and tariffs instituted under the industry's government auto policy contribute to high vehicle prices and the inefficient domestic production of motor cars in South $\mathrm{Africa}^{2}$. Domestic assemblers and component producers benefit from the regime by receiving higher profits being transferred from consumer surplus. The imminent challenge for the local industry is to maintain its export expansion path beyond the termination of the MIDP in the absence of costly government support schemes (Damoense \& Simon, 2004), and to become more globally competitive.

\section{PERFORMANCE OF THE AUTO INDUSTRY: SOME KEY FEATURES}

\section{Domestic Production}

Global auto production reached almost 55 million units of vehicles in 2002 as indicated in figure 2 below, increasing by about 10 per cent between 1995 and 2002. The countries of the Asia-Pacific region, which include, among others, China, Taiwan, Thailand, Australia and India, and except Japan, have contributed largely to the surge in vehicle output for the region. The Asian crisis of 1997-1998 saw world vehicle production drop. In South America, between 1997 and 1999 vehicle production was adversely affected by the economic crisis that took place in 1997.

Figure 2 below shows total vehicle production for the countries under study. In 1995 China produced 1,5 million units of vehicles compared to 3,3 million units in 2002; a spectacular rise of 120 per cent over the 7 year period. Over the same period India increased its vehicle production by 91 per cent from 629,000 units to 1,2 million units. By contrast, both the Australian market and South African market remained subdued with increases of almost 4 per cent over the same period. It should be noted that Australia imports more than 50 per cent of its vehicle output. However, in China and India, imported CBUs are not a threat to the domestic industries due to protective barriers applied to the industries. For instance, in China, import CBUs accounted for less than 3.5 per cent of the country's domestic market in 1998. Many of the afore-mentioned countries, especially India and China are experiencing overcapacity mainly attributable to large inflows of investments by TNCs in recent years. For example, China's production capacity is 2.5 million units and market demand in the region of 1.7 million units (Veloso \& Kumar, 2002). Given that their domestic markets are limited, if global demand does not match up to expectations in the future, global excess capacity could result in intense competition, increased consolidations and eventual plant closures in many countries. This will have harmful implications for developing countries. Governments may have to intervene to avoid further excess capacity.

\footnotetext{
${ }^{2}$ The study employs 1996 data.
} 


\section{Automotive Trade Balance}

The auto trade balance has always been a key worry for governments in developing nations. This has been a pertinent argument in favour of government intervention and trade policy restrictions. Table 3 below shows trade balance of automotive products in a few countries. In particular, in Australia the auto deficit reached about US\$ 8.3 billion and in China it reached US\$ 9.2 billion in 2003, respectively. South Africa's auto industry has also been experiencing a trade deficit fluctuating between US\$ 0.76 billion and US\$ 1.0 billion over the period 1998 to 2002, despite growing exports over time (DTI, 2003). Trade deficits have been persistent in most developing markets even in the light of rising exports due to tariff reductions stimulating the demand for imported auto vehicles and components. Although, exports have been growing over time for countries such as Australia, China and South Africa it has been largely because of falling tariff rates that contributed to the more than proportionate increases in imports coupled with their depreciating currencies. Widening auto trade deficits adversely affects a country's balance of payments.

Figure 2. Vehicle Production By Country 1995-2003*

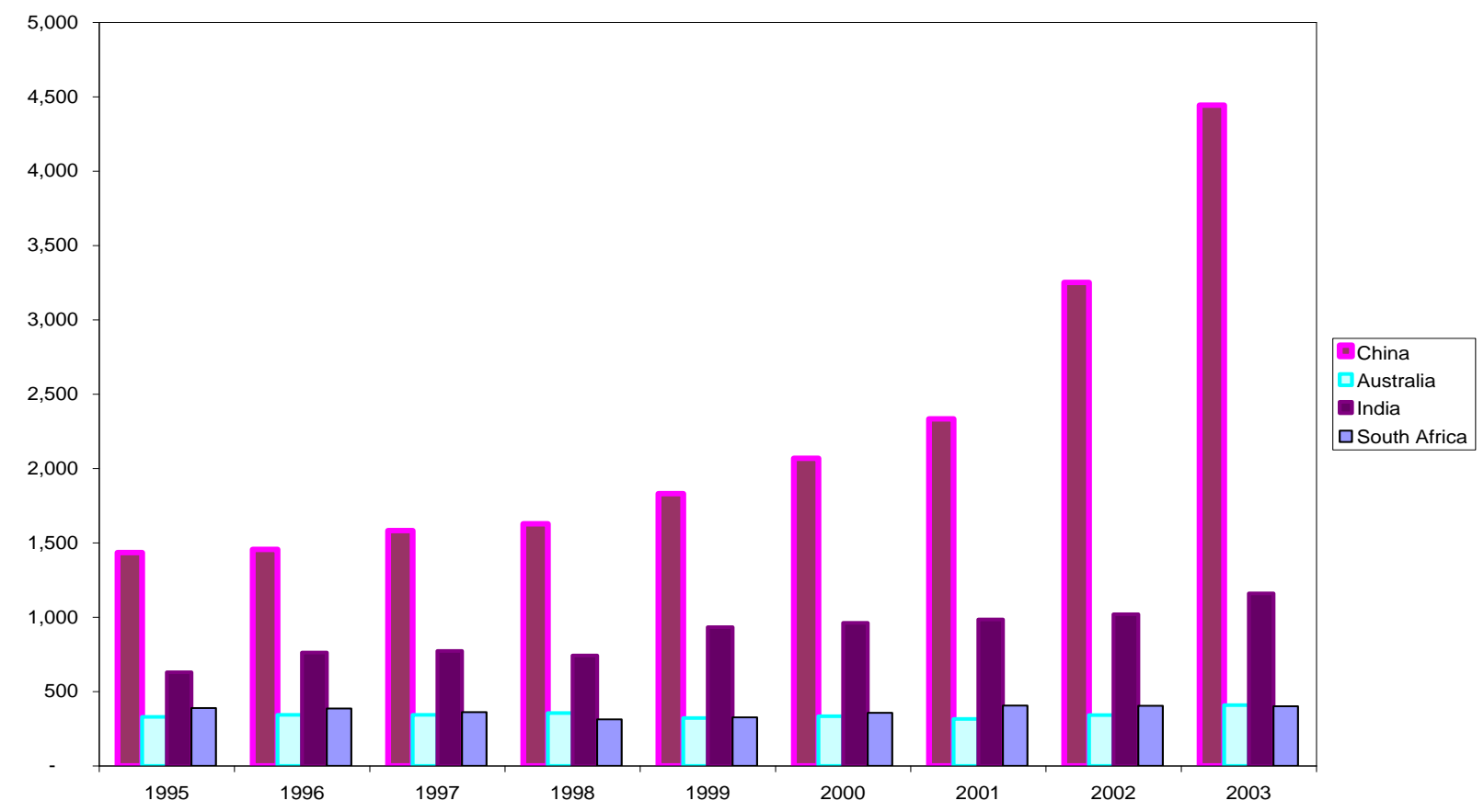

Sources: IMF Auto Report (2000), IMF Auto Report (2004), NAMSA (2003). *Figures for 2003 are forecasts except for South Africa. Notes: Vehicle production figures denote the sum of car and commercial vehicle figures. Figures for South Africa were obtained from NAAMSA (2003).

Table 3. Selected Countries: Balance of Trade in Automotive Products, 2003.

\begin{tabular}{|l|c|c|c|}
\hline Country/Region & Exports (US\$ million) & Imports (US\$ million) & Total Surplus/Deficit (-) \\
\hline European Union & 371,114 & 312,664 & 58,450 \\
\hline Japan & 102,734 & 11,130 & 91,604 \\
\hline United States & 69,245 & 181,283 & $\mathbf{- 1 1 2 , 0 3 8}$ \\
\hline Mexico & 30,132 & 20,194 & 9,938 \\
\hline Brazil & 6,530 & 2,876 & 3,654 \\
\hline China & 3,571 & 12,778 & $\mathbf{- 9 , 2 0 7}$ \\
\hline Australia & 2,767 & 11,101 & $\mathbf{- 8 , 3 3 4}$ \\
\hline South Africa & 3,030 & 3,380 & $\mathbf{- 3 5 0}$ \\
\hline
\end{tabular}

Source: World Trade Organization, International Trade Statistics (2004) 


\section{Automotive Employment}

A single argument favouring protectionism suggests that higher tariffs tend to raise employment levels. According to Tcha \& Kuriyama (2003), with tariff liberalization and the existence of economies of scale in production a fall in domestic vehicle prices can be expected and hence production and employment might rise. Automotive industry employment is primarily dependent on macroeconomic conditions, production and productivity levels, technological innovations, government and trade policies, among others. Worldwide employment effects in many auto sectors have been following a declining trend. In addition, it seems that the fall in total employment levels (assembly and components) can largely be explained by the drop in employment numbers in assembly operations relative to component industries. This has happened mainly as a result of restructuring production and supply chains (IMF, 2004).

In South Africa, industry employment decreased from 119, 600 in 1995 to 91,200 over the period 1995 to 2001 (NAAMSA, 2003). Contrary to happenings in the world auto industry, most of the contraction prevailed in the component industry. Occurrences in other developing countries such as Brazil and Argentina show that tariff liberalization results in rising demand for foreign vehicles, thereby harmfully affecting the domestic production of cars, and in turn transmits into elevated levels of unemployment in auto sectors (Chudnovsky et al, 1996, Humphrey, 1998). On the other hand, in Australia employment in the auto industry increased by 16 per cent from 53,915 workers in 1993-1994 to 62,661 in 2000-01 (ABS, 2002). However, employment may be adversely affected in the future given the planned closures by Japan's Mitsubishi, as mentioned elsewhere and other TNCs that may well follow. Global over capacity might contribute to further possibilities of plant closures and consolidations in the global auto industry that will have a negative impact on world-wide employment. The adoption of Japanese concepts and best practices such as just-in-time (JIT) and lean production methods, contributed to high quality auto products and improved productivity levels in the industry. In particular, better productivity levels have been experienced in most of the countries under study in this paper, which probably also played a role to an extent to the decline in employment echelons and rising production in the auto sectors.

\section{Technology}

Over the years automotive policy reform contributed significantly to technology trajectories and technology paradigms in the industry. Historically, under protective regimes, local firms had to develop expertise, design and adapt import technologies to local manufacturing conditions. Hence, technological learning transpired and technological capability was reflected in the localization of components during this era of import substitution industrialization (Black, 1996; Katz, 2001). Increased trade and investment liberalization in the 1990s contributed to the effortless facilitation of the surge of technologies and the utilization of technical know-how across geographical borders (Katz, 2001). In addition, the swift change in automotive technologies and information technologies (IT) or ecommerce has reclassified the processes of manufacturing and organization in the automotive industry. The fast process of innovation and technology advancement has resulted in constant and rapid introductions of auto products, processes and technologies facilitated by the transformation of M\&As and JVs in the global auto industry.

Governments have an important role to play with respect to providing incentives to boost R\&D investments and to stimulate innovation technologies. Innovations are invented by R\&D activities of firms and other technologycreating activities (Barnes \& Lorentzen, 2003; Mani, 2001). Governments National Innovation Systems (NISs) policy represents an important tool for fostering technological innovative activities and R\&D challenges, and to strengthen competitiveness, particularly for auto firms in developing countries. An important link has been established between NIS policy and economic development and growth. The concept of NIS is based on the principle of comprehending the interactions among participants or institutions (such as private firms, universities and public research institutions) involved in innovation is key to improving technology performance and progress (OECD, 1997), and hence contribute to economic development and growth. Much of the research literature suggest that NIS polices of developing countries are not well-established and deficient in most respects to provide meaningful support to foster technological innovation. Thus, there is a need for an integrated NIS policy to cultivate truly internationally competitive domestic automotive industries in developing markets. We require the establishment of first-class centres of excellence in key enabling technologies and novel education initiatives in critical areas of engineering and the sciences. India has a 
comparative advantage in the areas of engineering and IT in India. However, Mani (2001), maintain that there is an inadequate supply of qualified engineers, skilled technicians and scientists in India. The situation tends to be inferior in many other developing countries that do not possess the appropriate levels of technologies, skills and expertise.

\section{SOME LESSONS FOR SOUTH AFRICA AND OTHER DEVELOPING ECONOMIES}

Inconsistent with the TRIMS accord, all local content deals that are in existence, especially after 2000 are regarded to be WTO-illegal. So, for a country like India, the appropriate response would be to discontinue local content rules, and hence to rely solely on tariffs applicable to CBUs and components, preferably at lower levels. Although, South Africa has discontinued local content requirements since September 1995, it continues to follow export facilitation which will continue until 2012 under the current MIDP and thus continue to increase the industry's effective rate of protection. Tariff-based import protection in the auto industry is however more desirable for South Africa and other developing countries than TRIMS-related arrangements. In particular, for small open economies, especially developing economies, tariff reduction schedules must be appropriate for the level of development of the country.

Arguably, global free trade arrangements (FTAs) are superior to regional trade arrangements (RTAs), however the latter have been more illustrious over the last decade than the former (Bardouille, 2001), especially amongst developing countries involved in a Customs Union (CU) pact. Member countries of a CU benefit from preferential lower tariff rates applied within the union, and might be welfare improving for the member countries. South Africa and Australia have limited domestic markets in contrast to India and China who have large markets that can offer TNCs a number of associated advantages that might not be the case with South Africa and Australia. According to Humphrey (2003), scope for increasing scale through regional integration is not a likely option for the two countries. For South Africa, however, recent talks are ongoing between SACU members to establish preferential trade agreements with the MERCOSUR states and India. This is likely to have positive trade potential effects for South Africa and the rest of Developing Africa, especially in terms of automobiles and auto parts. It is plausible to assume that this type of trading agreements will increase market access and be welfare improving for the countries concerned. Further study is needed in this regard.

Main challenges for South Africa and other developing auto producing countries are to become increasingly internationally competitive and to attract new and increased levels of foreign direct investment (FDI). In order to attract more FDI and to establish and strengthen ties with global parent firms so as to tap into new markets and gain market share in existing markets in the future, South Africa and other developing nations need to emphasize and reinforce their competitive edge in terms of their comparative advantage in flexible production capabilities, good infrastructure, cost advantages - cheap electricity and labor, raw material availability - platinum, chromium, stainless steel, etc. (DTI, 2003). Furthermore, to strengthen existing capabilities of flexible manufacturing in auto production and further improve productivity levels.

Given the effects of rapid global innovation in new product technologies, there exists a strong need to sustain technological innovation and R\&D activities in auto industries in developing nations. This can be achieved if auto local industries (OEMs and all tiers of component suppliers) adopt more aggressive attitudes in driving effective collaborative initiatives with tertiary institutions and relevant scientific institutions, including sourcing strong support from governments. The most efficient tool to facilitate this in developing countries is to establish effective NIS policy.

Evidence suggests that the foremost problem facing local assembly firms of developing economies is the small scale production (Veloso \& Kumar, 2001; Humprey, 2003). We recommend that local OEMs reduce or discontinue producing an assortment of vehicle models, especially low-volume ones (thus importing them), and concentrate on more high-value-volume vehicles that encompass valuable technological features. This will encourage OEMs to specialize and reap benefits of economies of scale in production, and may actually lower vehicle prices. Also, as already mentioned elsewhere, OEMs need to attract greater inflows of FDI and strengthen global relationships with TNCs to sustain export production levels and export markets. In particular, auto component firms must persist in seeking new markets to do business with. Under the country-specific government policies as discussed here, in particular, the varieties of assistance schemes provided to local industries tend to encourage the inflow of FDI 
into host countries. Evidence clearly indicates that this has happened in all the countries under study. For instance, Australia's ACIS and South Africa's MIDP has provided fervent incentives for the major automakers to establish production centres and build-up productive capacities in these countries.

Although, automotive production has increased for most economies, specifically in respect of exports, employment in auto industries have declined. There is a possibility that this trend is likely to persist especially in developing countries where the current and projected prevalence of HIV/AIDS is a major concern. Production and productivity levels might be adversely affected by higher absenteeism, ill workers, and re-training and new recruiting of workers, among others, that will contribute to lower quality and productivity levels resulting in falling employment and lost domestic production of auto products, as well as rising costs of production for firms. In conjunction with economic growth and stability in inflation and interest rates, and domestic exchange rates, important microeconomic reforms that include human resource support and development programmes - education and training (technical, engineering, IT, HIV/AIDS, etc.) - and other support (eg. emotional) are vital. This is so especially for auto workers facing job losses, thus enabling them to be transferred to other sectors within the broader manufacturing sectors of their economies (Damoense \& Simon, 2004).

\section{CONCLUSION}

Automobile manufacturing has traditionally played an important role in stimulating economic growth and development. For most developing countries, the government has considered the industry a key sector for the development of the economy. Accordingly, the future of auto industries is of considerable importance. Sustaining and increasing export production levels of autos and auto components remains pertinent for the potential growth of these industries. It is evident that as many of the developing economies, including South Africa and India, phase-down or phase-out some of the TRIMS-illegal schemes, novel ones are instated to replace them, persistently increasing the effective protection rate of the local industries, thereby contributing to economically inefficient automotive industries. However, in the light of current auto policies already in place, some modifications may be deemed necessary to make them more effective, especially since excess capacity is being experienced in a number of developing countries, including China and India. In particular, consideration should be given to ways of increasing the size of domestic markets by implementing strategic regional trade agreements, making vehicles more affordable to average persons and at the same time increasing domestic production and employment levels in the industry. Greater investment inflows and enhancing support for technological innovation and R\&D activities in the auto industry in the future are also essential.

\section{REFERENCES}

1. ABS (2002). Australian Bureau of Statistics <http://www.abs.gov.za〉

2. ACMA (2004). Industry Statistics: Vehicle Industry and Auto Component Industry. Automotive Component Manufacturers Association of India <http://www.acam.ind>

3. Audet, D (1998). Market Access in the Automobile Sector. The OECD Observer, No 209 December 1997/January 1998.

4. Bardouille, N. (2001). Market Access and Trade Policy: Theory and Practice in the Context of the FTAA. OECS Economic Affairs Division.

5. Barnes, J. and Lorentzen, J. (2003). Learning, Upgrading and Innovation in the South African Automotive Industry. Paper prepared for Workshops on Understanding FDI-Assisted Economic Development TIK Centre, University of Oslo, 22-24 May.

6. Black, A. (1996). Learning, Technical Change and the Trade Regime in the South African Automotive Component Sector, Development Policy Research Unit (DPRU), University of Cape Town, Cape Town.

7. Cavalcante, L. R. \& Underman, S. (2004). The Cost of Structural Change: A Large Automobile Plant in Brazilian Less Developed Region, Discussion Paper, Regional Economics Applications Laboratory (REAL), April.

8. China Embassy (2004). China Issues New Auto Rules. Accessed 26 July $2004<$ http//:www.chinaembassy.org/eng/gyzg/t127767.htm> 
9. Chudnovsky, D., Lopez, A., and Porta, F. (1996). Intra-industry Trade and Regional Integration: The Case of the Auto Industry in Argentina, Innovacion Tecnologicaacenit - Centro de Investigaciones para la Transformacion, January. <http://www.fud-cenit.org.ar/publicaciones/Intra-industry.htm>

10. Damoense, M. Y. and Simon, A. (2004). An Analysis of the First Phase of South Africa's Motor Industry Development Programme (MIDP): 1995 to 2000. Development Southern Africa Journal, vol 21(2), pp251269.

11. Damoense, M. Y. and Agbola, F. (2004). Economic Analysis of Welfare Costs of Protection in the Automotive Industry in South Africa. Unpublished paper.

12. Damoense, M.Y. (2001). An Analysis of the Impact of the Motor Industry Development Programme (MIDP) on the Development of the South African Motor Vehicle Industry, Unpublished Master of Commerce Dissertation, Economics, University of Durban-Westville, South Africa, Durban.

13. DTI (2003). Current Developments in the Automotive industry. Department of Trade and Industry, Republic of South Africa, Pretoria, September.

14. EUI (2004). Economic Intelligence Unit Database.

15. FCAI (2002). FCAI Submission: Inquiry into Business Commitment to R\&D in Australia. Federal Chamber of Automotive Industries Submission to House of Representatives Standing Committee on Science and Innovation, September.

16. Flatters, F. (2002). From Import Substitution to Export Promotion: Driving the South African Motor Industry. <http://qed.econ.queensu.ca/faculty/flatters/writings>

17. GI (2004). Auto Manufacturers in China: Profiles. Global Information, Inc. United States of America.

18. Humphrey, J. (2003). Globalization and Supply Chain Networks: The Auto Industry in Brazil and India. Global Networks, vol 3, (2), pp121-141.

19. Humphrey, J. (1998). Globalization, FDI and the Restructuring of Supplier Networks: The Motor Industry in Brazil and India, In: Kagami, M., Humphrey, J. and Piore, M. (eds), Learning, Liberalization and Economic Adjustment, Institute of Developing Economics (IDE), Japan.

20. ICRA (2003-04). <http://www.icraindia.com>

21. IMF Auto Report (2004). The Auto Industry: Challenges and Strategies for Trade Unions. Automotive Department, International Metalworkers' Federation.

22. IMF Auto Report (2000). Mergers, Acquisitions and Alliances, Industry Review and Outlook, Employment Situation, Long-term Vehicle Sales Prospects. Automotive Department, International Metalworkers' Federation.

23. Indiamart.com (2004). <http://www.indiamart.com/ind>

24. Katz, J. M. (2001). Structural Reforms, Productivity and Technological Change in Latin America, Economic Commission for Latin America.

25. Mani, S. (2001). Government, Innovation and Technology Policy, An Analysis of the Brazilian Experience during the 1990s. The United Nations University, ITECH, Discussion Paper Series, December.

26. Masciltelli, B. (1999). Australia: Automotive Industry. Department of Commerce, National Trade Data Bank, USA, 22 June. <http://www.tradeport.org/ts/countries/australia/isa/isar0018.html>,

27. Ministry of Commerce, China (2003). Chinese Official Touts New Auto Rules As WTO Compliant, Necessary To Manage Growth 12 September. 〈http://wwwinsidertrade.com>

28. NAAMSA (2003). Annual Report 2002/2003. National Association of Automobile Manufacturers of South Africa, Pretoria.

29. NAAMSA (2002). Annual Report 2001/2002. National Association of Automobile Manufacturers of South Africa, Pretoria.

30. OECD (1997). National Innovation Systems. Organization for Economic and Cooperation and Development, France, Paris

31. Pursell, G. (2001). Australia's Experience with Local Content Programs in the Auto Industry: Lessons for India and Other Developing Countries, World Bank, Working Paper no. 2625. 22 June.

32. Runckel \& Associates (2004). The Chinese Government has Released A New Auto Policy that is Applauded as More Transparent but is deigned to Slow Auto Sales. <http://www.business-in-asia.com/china_auto.html>

33. SIAM (2004). Society of Indian Automobile Manufacturers. <http://www.siamindia.com>

34. Takacs, W.E. (1992). How Import Protection Affects the Philippines' Motor Vehicle Industry, Country Economics Department, The World Bank, Working Paper WPS 1035, November. 
35. Tcha, M. and Kuriyama, T. (2003). Protection Policy Under Economies of Scale - Welfare Effects of Tariffs on the Australian Automotive Industry. Journal of Policy Modeling, 25, pp 655-672.

36. Thursfield, D. W. (2003). Executive vice-president of Ford. Interview with Chinese Foreign Ministry, 2 May.

37. UNCTAD (2004). Regionalism and South-South Cooperation: The Case of Mercosur and India. United Nations Conference on Trade and Development, Eleventh Session, Sao Paulo, 13-18 June.

38. Veloso, F. and Kumar, R. (2002). The Automotive Supply Chain: Global Trends and Asian Perspectives. Economic and Research Department. Working Paper Series No. 3, Asian Development Bank, January.

39. Vermeulen, N. (2004). Unfounded Allegations. Finance Week, 12-16April, pp5-6.

40. World Bank (2004). World Development Indicators Database Online <http://www.worldbank.org>.

41. WTO (2004). World Trade Organization, Internat

\section{NOTES}

